\title{
PERSPECTIVES IN THE APPLICATION \\ OF IMMUNOCORRECTOR - TRANSFER FACTOR TM \\ IN IMMUNOPROPHYLAXIS PROGRAMMES AND \\ IMMUNOREHABILITATION
}

\author{
Alexey Ya. Chizhov', Algimantas Kirkutis², Artūras Razbadauskas², \\ Jurgita Andruškiené $\dot{2}^{2,3}$ \\ Ecological Department of Russian People’s Friendship University, \\ The Scientific Advisory Board of 4Life Research Company ${ }^{l}$, \\ Klaipèda University ${ }^{2}$, \\ Klaipèda State University of Applied Sciences ${ }^{3}$
}

\begin{abstract}
Background. Human health is largely determined by the body's resistance to various damaging factors and, in particular, the functional state of its immune system. The use of unique, new generation immunomodulators in prevention of diseases is promising.

Goal of the research was to define the perspectives in the application of immunocorrector Transfer factor ${ }^{\mathrm{TM}}$ in immunoprophylaxis programmes and immunorehabilitation analysing and summarizing scientific articles.

Methods. Systemic literature overview was performed, including 77 scientific articles and conference proceedings in English, published in the period from 1949 to 2016. The main inclusion criterion was clinical trial or literature review, analysing the effect of immunocorrector on human health in cases of different disorders.

Results. Transfer factors are molecules that communicate antigenic immunological information intracellularly from a donor to a recipient. Mammalian Transfer factors, including those of humans are small molecules between 3,500 and 10,000 Daltons. Transfer factor's functions of cell-mediated immunity and non-specific immunological activity differ from the functions of antibodies. Transfer factors are divided into three fractions: the inductors that provide rapid immune response and general readiness of the immune system; suppressors, which regulate the intensity of the immune response, preventing allergic and autoimmune reactions; antigen specific Transfer factors with a set of certain antigens, allowing quick adjusting of the immune system to recognize many bacterial and viruses.

Conclusions. Transfer factors have no side effects and are considered as highly effective in treatment of infectious, parasitic, oncological, dermatological, venereal and somatic diseases, so are highly recommended for preventive purposes and decreasing of aging.
\end{abstract}

Keywords: transfer factor, immunoprophylaxis, immunorehabilitation.

\section{INTRODUCTION}

According to the modern concepts, $80 \%$ of human diseases are directly or indirectly associated with adverse environmental conditions. Therefore, the steady increase in diseases of civilization requires special attention to not only of environmentalists and experts in the field of preventive medicine, but government circles in all countries as well. It is not surprising that, related to scientific and 
technical progress environmentally induced pathology was formed as a separate issue, highly relevant for any state (Chizhov, 2008).

It has been generally recognized that human health is largely determined by the body's resistance to various damaging factors and, in particular, the functional state of its immune system. Our age is characterized by ever-increasing loads on the human immune system as a result of number of reasons, including environmental pollution, lack of nutrients caused by violations of food structure, the side effects of medications, bad habits (smoking, drugs), infections, including HIV, neuro emotional stress, and other factors. Despite the fact that the potential of compensatory-adaptive mechanisms and adaptive reserves of the human body is large enough, sooner or later, the problems in functional systems to ensure homeostasis will inevitably appear and, as a consequence, the depletion of homeostatic human potential will occur. Constant exposure of anthropogenic environmental pollutants on human body depletes the capacity of the immune system, the body's adaptive reserves and the emergence of a wide range of diseases of civilization. This is a partial explanation for increased frequency of cancer and other diseases, which are characterized by common disorders in the body and a significant suppression of the immune system (Agadzhanian, Chizhov, 2003).

Immunorehabilitation in many infectious and somatic diseases is becoming one of the most important parts of pathogenic therapy (Sepiashvili, 2000). The need for such approach is determined with adaptability and frequent intracellular persistence of an infectious agent and also the absence of quite intense immune response from the microorganism. In addition, a large stratum of the population suffers from secondary immunodeficiency caused with adverse effects on the body of social, environmental and other factors (Ilyina, 2000; Grammatikos, Tsokos, 2012). A special place among the so-called 'new' infections take mixed infection, as a result of simultaneous or sequential infection by different agents the clinical manifestations of the disease are undergoing significant changes. Their more frequent appearance is explained by various immunopathological conditions (Unicomb et al., 1996).

Goal of the research was to define the perspectives in the application of immunocorrector Transfer factor ${ }^{\mathrm{TM}}$ in immunoprophylaxis programmes and immunorehabilitation analysing and summarizing scientific articles.

\section{METHODS}

Systemic literature overview was performed, including 77 scientific articles and conference proceedings in English, published in the period from 1949 to 2016. The main inclusion criterion was clinical trial or literature review, analysing the 
effect of immunocorrector on human health in cases of different disorders. Scientific literature search was performed in the period of 2015-2016, the bibliographic databases "EBSCO", "Medline", "PubMed", "MedScape", "Google", "ScienceDirect" and "BioMed Central" were used. All articles were included in the analysis. Search of the articles was performed using the keywords: transfer factor, immunoprophylaxis, immunorehabilitation, prevention, disease, somatic, infectious, parasitic, oncological, dermatological, venereal.

\section{RESULTS}

New perspectives in the use of natural immunomodulators. The steady increase in atopic reactions, complicating the course of many diseases and hampers the effective therapy, autoimmune processes that are in the basis of progressive pathological states, require at doctors not only basic knowledge of immunology, but also the search for new approaches to therapies of these states. The main focus of the active non-specific immunotherapy at the present stage is the use of interferon inducers, stimulant of macrophages activity, $\mathrm{B}$ and $\mathrm{T}$ lymphocytes, natural and recombinant interferons have antiviral and immunomodulation effects as well as of endogenous regulators of immune reactions such as interleukins and other cytokines (Bazhan, Belova, 1998; Haller et al., 2009). Parenteral insert of cytokines is often accompanied by hyperergic reactions (Paul, Seder, 1998).

Most natural for the human endogenous immune modulators are those based on the substance involved in the regulation of immune processes in humans and animals. As known, endogenous immunomodulators include interferons, interleukins, and thymus peptides preparations immunocompetent cells in the bone marrow. The possibility of using natural endogenous nonspecific immunomodulators opens new perspectives in immunorehabilitation in various infectious and somatic diseases. In this regard, the use of a new generation of unique immunomodulators, which include transfer factor, is promising (Lawrence, 1955, 1974; Lawrence, Borkowsky, 1983; Fudenberg, 1989; Dwyer, 1996; Oganova et al., 2003).

Unique properties of transfer factor. Transfer factor, small polypeptide that is produced by a type of white blood cell called a T-cell and that when passed from one person to another produces cellular hypersensitivity. It was discovered in 1949 by American immunologist Henry Sherwood Lawrence at New York University (Lawrence, 1949). He demonstrated that functions of cell-mediated immunity (CMI) could be transferred from one individual to another by way of low molecular weight extracts of white blood cells. Transfer factors could transfer delayed-type hypersensitivity (DTH) of a specific form from a skin test positive individual to 
a skin test negative individual who subsequent to the transfer would skin test positive for that antigen (Lawrence, 1949). In a subsequent study in 1955 he demonstrated that DTH could be passed serially, first from a skin test positive individual to a test negative individual, who became test positive, then 6 months later from the second individual to another test negative individual who became test positive (Lawrence, 1955). At the time, antibodies were the focus of immune research and little was known of the importance of DTH and of the involvement of T-cells in immune response. Transfer factors promote wellness via cell-mediated immunity. These compounds are components of colostrum, an infant's first meal. They bridge the generational gap by passing cell-mediated immunity from mother to infant.

Transfer factors are molecules that communicate antigenic immunological information intercellular and from a donor to a recipient. They support immune function through cell-mediated immunity. Transfer factors, which carry antigen specific information to which all tested immune cells respond, are produced by mononuclear cells, serve to support, and improve immune mediated pathways. Mammalian transfer factors, including those of humans are small molecules between 3,500 and 10,000 Daltons (Lawrence, 1969; Fudenberg, Pizza, 1993). Transfer factors are polypeptides that consist of 40 to 44 amino acids (Kirkpatrick, 2000) and have a conserved region and a variable region. From a molecular biological standpoint, these two properties are analogous to antibodies; however, transfer factor's functions of CMI and non-specific immunological activity differ almost completely from the functions of antibodies. The molecules that have a molecular weight of less than 3,500 Daltons modulate immune response but they do not transfer DTH (Fudenberg, Pizza, 1993).

Transfer factor is unique in that the hypersensitivity it transfers to cells has properties of both passive and active immunity. Transfer factor is a dialyzable extract, meaning that it can be separated out of an individual's immunologically active T-cells. Transfer factor is prepared from the blood, but from white blood cells rather than from whole serum. The white cells are separated from the serum, concentrated, and disrupted by mechanical means to free the cell contents. The cell extract is filtered through a membrane sieve, which allows only the small molecules of the cells containing transfer factor to pass through in solution (Kirkpatrick, Smith, 1976).

Upon further study of the transfer factors important discovery was made - they are all the biochemical composition and functional properties were the same regardless of the species of vertebrates (humans, animals, birds). Universality of transfer factors for most living systems has shown that these peptides are actually immune active compounds, which regulate quality of the immune response - its strength, speed and specificity. Transfer factors are divided into three fractions: 
inductors, which provide a quick immune response and general readiness of the immune system; suppressors, which regulate the intensity of the immune response, preventing allergic and autoimmune reactions; antigen specific transfer factors are a set of certain antigens, allowing to adjust quickly the immune system to recognize many bacterial and viral pathogens, and effectively protect themselves by forming a targeted immune response, i.e. to raise immune cells of the immune system. Until now, among a huge arsenal of pharmacological means there no products, running simultaneously in three directions, two of which are opposite the stimulation and inhibition. Only nature could create such a wonderful defence mechanism against alien foreign organisms to environmental factors. In published studies on transfer factors, the authors expressed the view that the new-born for the first time meets the transfer factor, getting them from the mother's colostrum (Kirkpatrick, 1993, 1996; Fudenberg, Pizza, 1994). However, given the very small amino acid composition of peptides and low molecular weight, there is a reason to believe that they penetrate through the mother's placenta to the mother to the fetus already in utero and stimulate its cells, starting with the 3rd month of gestation from the time of formation of the circulatory system of the fetus. For comparison, we can point to gamma interferon (chain of 166 amino acid residues, a molecular weight up to 90000 Daltons) or IgG - molecular weight greater than 150000 Daltons, easily penetrate through intact placenta. In the first hours after birth a child receives from the mother's colostrum immunoglobulins - IgA, IgM, IgG, lysozyme, lactoferrin, T lymphocytes, B lymphocytes, dendritic cells, hormones and cytokines (including transfer factors) that further directs new-born's immunity against the most common infectious diseases. Getting by a new-born of transfer factors from colostrum is of particular importance. It is important to remember that at an early age, and especially in the first year of life the humoral immunity predominates at a child (Th2), his body is protected from the effects of infectious mostly with antibodies. Only 10-12 years a very efficient cell-mediated immunity (Th1) forms, and then the macro-organism acquires a full immune response to attack of infectious microorganisms. Transfer factors 'teach' and 'train' ripening cells, increasing the synthesis of antibodies (activation of B-lymphocytes) and stimulating the cell-mediated immunity (increased functional activity and number of natural killer cells, helper CD4, suppressor, cytotoxic CD8 T cells, etc.), and increasing levels of endogenous interferons (Bokovoy, Egorov, 2014).

Application of transfer factor in clinical practice. Transfer factors do not cause any negative effects. Since 1949 there have been no reports on the development of any adverse reactions resulting from its use, even in case of increasing doses in a clinical setting or in cases of taking them for several years. Interesting observations G. Pizza et al. (1993, 1996, 2006), which have been using a trans- 
fer factor in clinical practice for over 25 years. Since 1974, 1647 patients have got treatment with transfer factor with good and excellent results. Among patients treated with transfer factor 439 patients with viral infections, 643 cancer patients, 287 patients with fungal lesions, 74 patients with chronic fatigue syndrome, 51 patients with AIDS and 153 patients with autoimmune diseases. Transfer factor was administered to these patients either intramuscularly or orally. About a third of these patients were followed for more than 20 years, and in all that time never mentioned effects of acute or chronic toxicity of transfer factor, which once again confirms their effectiveness and safety. In cancer patients, which in addition to the basic regimen received, transfer factor has greatly increased the effectiveness and tolerability to radiation therapy and chemotherapy, and the number of complications was significantly lower.

Enough effective results when using Transfer factor for leukaemia at both children and adult patients (Steele et al., 1980). In one of the studies is to determine the safety and efficacy of Transfer Factor in accelerating the hematopoietic recovery in patients with acute leukaemia's (AL), following intensive therapy to induce remission of the disease. Twenty-two patients with different types of AL (16 AML, 3 $\mathrm{BC}-\mathrm{CML}$ and $3 \mathrm{ALL}$ ) were studied. The patients were divided in two groups. The Group 1 (8 AML, 2 BC-CML and 1 ALL) received, after myelosuppression induced by chemotherapy, TF (1 unit daily, subcutaneous) until leucocyte count was > $2.5 \times 10$ (9) / 1 and platelet count $>80 \times 10(9) / 1$. Group 2 was considered the control group and did not receive TF. Treatment with TF accelerated the recovery of neutrophils, leucocytes, platelets $(\mathrm{p}<0.001)$ and haemoglobin $(\mathrm{p}<0.01)$. As a logical consequence, incidence and severity of infection and haemorrhage were lesser in the TF group than in the control group. There was no evidence that TF accelerated the re-growth of leukemic cells. It seems that TF is safe in AL, accelerating hematopoietic recovery (Fernandez et al., 1993).

Despite the fact that most studies of transfer factor products derived from animal material have proved an effective mean for the treatment of different diseases in humans. The main advantage of the transfer factor is its notable preventive activity. Initially it was thought that the source of transfer factors can be only human blood, and that they can be effective only when injected. For the preparation of injectable TF there were used donor blood, leukocyte culture and animal materials such as blood, spleen and lymph nodes. The negative side of the source is the risk of HIV infection or viral hepatitis; donated blood and blood from blood banks cannot provide the needs of industrial production; the inconvenience of application; high cost of the drug. Further studies have shown that transfer factors and maintain their effectiveness when administered orally. In 1980, researchers found that transfer factors are also present in colostrum. Today, many believe that cow colostrum 
is the best source of transfer factors. Benefits of using colostrum: the safety of the source; abundance of resources; simplicity and ease of use; economic affordability. In 1989, thanks to the use of high-tech patented process of ultrafiltration, concentrate of transfer factors was isolated from colostrum (Patent US N 4816563 dated 18 March 1989). The company 4Life Research (USA) has a license to use the concentrate having a trade name of Transfer Factor XF TM. The concentrate was purified from major milk proteins, fats, immunoglobulins and casein. That allows its use even in people with allergic to milk and lactose intolerance. To imagine the advantages of the concentrate prior to dry colostrum, it is enough to say, that to obtain $1 \mathrm{~kg}$ of concentrate requires $50 \mathrm{~kg}$ of dried colostrum. Furthermore, efficiency of transfer factors is maintained in the concentrate of transfer factors through the use of a special stabilization process. It is believed that transfer factors have the same degree of security as that of milk. In the US, the colostrum is produced from the milk of animals of higher class A and its production meets the same requirements as to the production of milk class A. Health condition of the animals is under strict control. Animals treated with antibiotics cannot be a source of milk or colostrum. The company 4Life Research USA has also developed a new technology isolation of transfer factors from eggs which was patented in October 2002 a patent (№ 6468534). New technology has allowed creating transfer factors specific to the infection, which, according to modern concepts, is pathogenic for the development of cardiovascular disease. According to its effects on the immune system products Transfer Factor products are significantly superior to other immunostimulatory agents. Independent in vitro studies on the comparative evaluation of the effectiveness of Transfer Factor and Transfer Factor Plus by comparing them with other immunomodulators in the study of killer cell activity showed that Transfer Factor enhances the immune response to the $103 \%$, Transfer Factor plus to - $243 \%$; colostrum increases it only $-23 \%$ ehinatseya $-43 \%$, and the juice of Noni (Morindo citrifolia) - 15\% (Oganova, 2002, 2003).

Transfer factor and aging society. The results of many years of experimental and clinical trials, and subsequently studies from leading clinics of Russia have established high immunocorrective effects of oral forms of transfer factors. They were highly effective in various infectious, parasitic, oncological, dermatological, venereal and somatic diseases. As evidence, presented in the literature, the immunocorrective effect of transfer factor is comparable to the effect of the most frequently used interferon, cytokine and other modern drugs immunomodulators. All the authors note that the use of oral TF variant derived from cow colostrum and chicken egg yolks, do not cause side effects, make it possible to obtain optimal treatment results and significantly reduce the duration of immunorehabilitation 
courses of therapy. Along with immunomodulation effect it is shown that transfer factors also have antioxidant, nootropic activity and increase working capacity.

A new, promising direction is detected by anti-aging effect, which manifests itself in the reduction of biological age. Recent years a novel approach to modern modulator of immune system, Transfer factor in combination with hypoxic therapy implication was suggested using Intermittent Normobaric Hypoxia. The results of ecological and physiological studies demonstrated prophylactic effect of Transfer factor ${ }^{\mathrm{TM}}$ in aging mice, as well as its effectiveness in reduction of biological age in men who live in the city. This immune corrector was used in two modes - as monotherapy and in combination with hypoxic stimulation. It was found that taking the immune corrective product Transfer factors ${ }^{\mathrm{TM}}$ for 6 weeks significantly improves the performance of individual biomarkers that characterize the degree of aging of the body, as well as in whole reduces the biological age by an average of 4.4 years. When used in combination with hypoxic training reduction of biological age is more notable (by an average of 9 years). In an experiment on mice the positive impact of Transfer factor ${ }^{\mathrm{TM}}$ on physiological indicators of old mice was observed, approaching to indicators of young animals. Conducted environmental and physiological research provides a basis to recommend practical use of Transfer Factor ${ }^{\mathrm{TM}}$ in a daily dose of $600 \mathrm{mg}$ in megapolis residents as one of the components in the integrated development of mechanisms for the prevention of premature aging (Dontsov et al., 2010 a, b; Chizhov et al., 2013 a, b, c, 2014).

Thus, deep, multisided study of natural and safe means immunorehabilitation remains one of the main directions of development of modern prophylactic and therapeutic rehabilitation branches in medicine. According to immunologist Professor A. A. Vorobyov et al. (2004), medicine uses “... a lot of immunomodulators uneven in their effectiveness because of the presence of side effects, ease of use, cost effectiveness. The most acceptable and adequate to the human body natural, so-called endogenous immune modulators, which are based on the substance involved in the regulation of immune processes in humans and animals." It should be added that in the endogenous immunomodulators the immunological experience is fixed and passed on from generation to generation in the evolution of living organisms. Transfer Factor derived from cow colostrum and chicken egg yolks is one of these endogenous immunocorrectors.

The interest of the scientific community indicates to transfer factors that since their discovery there have been published more than 3,500 scientific papers on the subject and conducted 12 international symposia. A wide range of clinical effects of Transfer Factor, demonstrated at the XI and XII International Symposium on the clinical use of transfer factors clearly demonstrate that formulations of transfer factor could be used healthy and sick people of all ages - from pregnant women, 
Perspectives in the Application of Immunocorrector - Transfer Factor TM in Immunoprophylaxis Programmes and Immunorehabilitation

very young children to the elderly patients in intensive therapy wards ICU. This has been repeatedly proved by the absence of side effects and high efficacy of Transfer Factor administrated orally.

\section{CONCLUSIONS}

Finally, it should be noted that the most promising will be the deepening of studies on the use of transfer factors in prevention of diseases, sports medicine and anti-aging medicine. It is important, in our opinion, to study the possibility of replacing the vaccination of children and adults, as well as the possibility of prevention of various epidemics and inclusion of transfer factors in everyday food.

\section{REFERENCES}

Agadzhanian, N. A., Chizhov, A. Ya. (2003). Diseases of Civilization. Encyclopaedia “Global Studies”. Moscow, Russia: Publishing house "Rainbow". P. 92-95.

Antypkin, Y. G., Lapshin, V. F., Drannik, G. N. et al. (2011). The effectiveness of transfer factors in a complex immunorehabilitation events. Guidelines, 47.

Aryaeva, M. M., Tsybikov, N. N. (2011). Effect of transfer factor on the dynamics of autoantibodies in the complex treatment of patients with diabetes mellitus. Proceedings of the III Russian Scientific-Practical Conference with International Participation (pp. 31-34). Novosibirsk.

Ballow, M., Dupont, B., Good, R. A. (1973). Autoimmune haemolytic anaemia in Wiskott-Aldrich syndrome during treatment with transfer factor. Journal of Paediatrics, 83 (5), 772-780.

Bazhan, S. I., Belova, O. E. (1998). Molecular genetic aspects of interferon induction and antiviral action. Vestnik Rossiiskoi Akademii Meditsinskikh Nauk, 3, 18-24.

Bokovoy, A. G., Egorov, A. I. (2014). Herpesvirus Infection in Children and Parents: Manual for Students, Pediatricians, Infectious Disease, Immunology. Moscow: Publishing House "Center for strategic conjuncture".

Chizhov, A. Ya. (2008). Modern Problems of Ecological Human Pathology: Monograph. Moscow: Publisher, Russian Peoples' Friendship University.

Chizhov, A. Ya., Santalova, V. A., Krut'ko, V. N. et al. (2007 a). Old tissue growth potential restoration by immune modulator - Transfer-factor (TF). International Association of Gerontology and Geriatrics. VI European Congress, July 5-8, Saint Petersburg. Russia.

Chizhov, A. Ya., Santalova, V. A., Krut'ko, V. N. et al. (2007 b). The influence of Transfer-factor on biological age of men. International association of Gerontology and Geriatrics. VI European Congress, July 5-8, Saint Petersburg, Russia.

Chizhov, A. Ya., Zenchuk, E. S., Dreimanis, M. (2014). A Method for Reducing Biological Age. Russia.

Chizhov, A. Ya., Zenchuk, E. S., Krut'ko, V. N. et al. (2013 a). Apply corrector Transfer factor immune system to reduce biological age in humans. Journal of Living Systems Technology, Radio, 10 (1), 41-46.

Chizhov, A. Ya., Zenchuk, E. S., Radysh, I. V. (2013 b). Reducing of the biological age with the combined effects of immunocorrector Transfer factor TM and hypoxic training. Journal of Living Systems Technology, Radio, $10(9), 41-46$.

Chizhov, A. Ya., Zenchuk, E. S. (2013 c). The rejuvenating effect of transfer factor. First International Conference on "Current Advances in Immunotherapy. Immunocorrection and Transfer factor" Conference abstract book, (pp. 11-13). June 7-8, Ulaanbaatar, Mongolia.

Choi, I. G., Esengeldieva, A. N. (2007). Alimentary support specific chemotherapy in primary pulmonary MDRTB using Transfer Factor. Proceedings of the IX Russian Congress of Dietitians and Nutritionists. Moscow.

Choi, I. G., Esengeldieva, A. M., Salieva, N. S. et al. (2006). The use of universal immunocorrector Transfer Factor in infectious and inflammatory diseases (review). Health and Disease Journal, 2 (51), 28-33. 
Dadali, V. A., Cancer, A. V., Stylites, E. S. et al. (2002). Some aspects of the action of the transfer factor. Biologically active food supplements and the problem of optimizing the supply. Proceedings of the VI International Symposium (pp. 62-63). Sochi.

Di Padova, F. (1979). A new approach to immunotherapy: The transfer factor. Minerva Medica, 26, 70 (25), 1773-1785.

Dontsov, V. I., Krut'ko, V. N., Chernilevsky, V. E., Chizhov, A. Ya. (2010 b). Method of Recovery Decreases with Age Potential Cell Growth Tissue (Tissue Rejuvenation). Russia.

Dontsov, V. I., Krut'ko, V. N., Chizhov, A. Ya. (2010 a). A Method For Reducing Biological Age (Rejuvenation). Russia.

Drannik, G. N. (2009). In vitro production IL-12, 15, 18 cells of patients with chronic herpes virus infection under the influence Advanced Transfer Factor. Integrative medicine. Materials of International Conference, May 30-31 (pp. 135-138), Kiev.

Dwyer John, M. (1996). Transfer factor in the age of molecular biology: A review. Biotherapy, 9, 7-11.

Fernandez, O., Diaz, N., Morales, E. et al. (1993). Effect of transfer factor on myelosuppression and related morbidity induced by chemotherapy in acute leukaemia. British Journal of Haematology, 84 (3), 423-427.

Fudenberg, H. H., Pizza, G. (1994). Transfer factor 1993. New frontiers. Progress in Drug Research, 42, 309-400.

Fudenberg, H. H. (1989). Transfer factor, past, present and future. Annual Review of Pharmacology and Toxicology, 29, 475-516.

Fudenberg, H. H., Wilson, G. B., Smith, C. L. (1980). Immunotherapy with dialyzable leukocyte extracts and studies of their antigen-specific (transfer factor) activity. Proceedings of Virchow Pirquet Medical Society, $34,83-87$.

Grammatikos, A., Tsokos, G. (2012). Immunodeficiency and autoimmunity: Lessons from systemic lupus erythematosus. Trends in Molecular Medicine, 18 (2), 101-108.

Granitov, V. M., Karbysheva, N. V., Sultanov, L. V. et al. (2002). Use of activated Transfer Factor in the treatment of patients with HIV. Journal of AIDS and Related Issues, 6 (1), 79-80.

Graybill, J. R. (1974). Transfer factor in diseases of the central nervous system. Advances in Neurology, 6, 107126.

Griscelli, C., Revillard, J. P., Betuel, H. et al. (1973). Transfer factor therapy in immuno-deficiencies. Biomedicine, 18 (3), 220-227.

Grob, P. J., Bläker, F., Schulz, K. H. (1973). Immune function and transfer factor. Deutsche Medizinische Wochenschrift, 98 (9), 446-451.

Haller, O., Weber F., Verh, K. (2009). The interferon response circuit in antiviral host defense. Verhandelinger Koninklijke Academie voor Geneeskunde van Belgie, 71 (1-2), 73-86.

Hitzig, W. H., Grob, P. J. (1974). Therapeutic uses of transfer factor. Progress in Clinical Immunology, 2, 69-100.

Ilyina, N. I. (2000). The secondary immunodeficiency. Diagnosis and treatment protocols. Allergy, Asthma and Clinical Immunologiya 1, 31-33.

Karbysheva, N. V., Karbyshev, I. A., Tatarintcev, P. B. et al. (2003). Transfer Factor in the treatment of patients with viral hepatitis. Siberian Journal of Gastroenterology and Hepatology, 16, 147-149.

Karbysheva, N. V., Sultanov, L. V., Belyh, S. I. (2002). White Laboratory diagnosis in the evaluation of the effectiveness immunorehabilitation opistorchosis. Works of Russian Conference: "Problems of medical enzymology", "Modern laboratory diagnostics technology of the new century" International Symposium: Pyridoxal phosphate-dependent enzymes: structure, molecular pathology and medicine (pp. 104-105), Moscow.

Kirkpatrick, C. H. (1996). Activities and characteristics of transfer factors. Biotherapy, 9 (1-3), 13-16.

Kirkpatrick, C. H., Smith, T. K. (1976). The nature of transfer factor and its clinical efficacy in the management of cutaneous disorders. Journal of Investigative Dermatology, 67, 425-430.

Kirkpatrick, C. H. (1993). Structural nature and functions of transfer factors. Annals of the New York Academy of Sciences, 685, 363-368.

Kirkpatrick, C. H. (2000). Transfer factors. Identification of conserved sequences in transfer factor molecules. Molecular Medicine, 6, 332-341.

Kisielewskiy, M. V., Halturina, E. O. (2003). Transfer Factor Plus in the treatment of patients with gastric cancer. Works of scientific-practical conference with international participation Immunorehabilitation in infectious and inflammatory diseases, November 29 (pp. 33-38), Barnaul.

Lawrence, H. S., Borkowsky, W. (1983). A new basis for the immunoregulatory activities of transfer factor. An arcane dialect in the language of cells. Cell Immunology, 82, 102-116.

Lawrence, H. S., Borkowsky, W. (1996). Transfer Factor current, status and future prospects. Biotherapy, 9, 1-3. 
Perspectives in the Application of Immunocorrector - Transfer Factor TM in Immunoprophylaxis Programmes and Immunorehabilitation

Lawrence, H. S. (1949). The cellular transfer of cutaneous hypersensitivity to tuberculin in man. Proceedings of the Society for Experimental Biology and Medicine, 71, 516-522.

Lawrence, H. S. (1955). The transfer in humans of delayed skin sensitivity to Streptococcial M substances and to tuberculin with disrupted leukocytes. Journal of Clinical Investigation, 34, 219-230.

Lawrence, H. S. (1969). Transfer factor. Advances in Immunology, 11, 195-266.

Lawrence, H. S. (1974). Transfer factor in cellular immunity. Harvey Lectures, 68, 239-350.

Letifov, G. M. (2004). Transfer Factor - Unique Immunoregulatory Agent. Barnaul.

Levin, A. S., Spitler, L. E., Stites, D. P. et al. (1970). Wiskott-Aldrich syndrome, a genetically determined cellular immunologic deficiency: Clinical and laboratory responses to therapy with transfer factor. Proceedings of the National Academy of Sciences USA, 67 (2), 821-828.

Lobuglio, A. F., Neidhart, A. J. (1974). A review of Transfer Factor immunotherapy in cancer. Cancer, 34, $1563-1570$.

Lykov, S. G., Nemchaninova, O. B., Chernikova, E. V. et al. (2002). Experience of using Transfer Factor in dermatology. Siberian Journal of Dermatology and Venereology, 3, 34-35.

Matz, A.N. (2001). Again, about the preparations "transfer factor" as a means of immunotherapy. Journal of Medical Immunology, 3 (2), 328-329.

Moulias, R., Goust, J. M., Reinert, P. et al. (1973). Transfer factor of cellular immunity. Preliminary therapeutic trials during specific immunologic deficiencies of an antigen in human clinical practice. La Nouvelle Presse Medicale, 19, 2 (20), 1341-1344.

Mutz, I., Lankford, J., Humphrey, G. B. (1974). Biologic and clinical implications of transfer factor. Southern Medical Journal, 67 (7), 837-840.

Oganova, E. A., Mc Causland, C. W., Hennen, U. D. (2002). (4-Life Research, USA). Transfer factors - a new generation of biologically active additives to food. Proceedings of the VI International Symposium "Dietary supplement to food and nutrition problems of optimization" of Sochi, November 5-7 (pp. 192-193).

Oganova, E. A., Mc Causland, C. W. (2003). Transfer factors - natural immunocorrectors. Collection of scientificpractical conference with international participation. Immunorehabilitation in infectious and inflammatory diseases, November 29 (pp. 22-26), Barnaul.

Paul, W. E., Seder, R. A. (1998) Lymphocyte responses and cytokines. Cell, 76, 241.

Pinaev, C. K., Pinaeva, O. G., Chizhov, A. Ya. (2014). The first experience of therapy of esophageal cancer using immunocorrector Transfer Faktor ${ }^{\mathrm{tm}}$. Journal of Living Systems Technologies, 11 (4), 59-62.

Pizza, G., Amadori, M., Ablashi, D. et al. (2006). Cell mediated immunity to meet the avian influenza A (H5N1) challenge. Medical Hypotheses, 67, 601-608.

Pizza, G., Chiodo, F., Colangeli, V. et al. (1996 b). Preliminary Observations using HIV-specific Transfer Factor in AIDS. Biotherapy, 9 (1-3), 41-47.

Pizza, G., De Vinci, C., Fomarola, V. et al. (1996 a). In vitro studies during long-term oral administration of specific Transfer Factor. Biotherapy, 9 (1-3), 175-85.

Pizza, G., De Vinci, C., Viza, D. et al. (1994).Transfer Factor in malignancy. Progress in Drug Research, 42, 401-421.

Pizza, G., Viza, D., Vinci, D. et al. (1996 c). Orally administered HSV-specific transfer factor (TF) prevents genital or labial herpes relapses. Biotherapy, 9 (1-3), 67-72.

Potter, H., Rosenfeld, S., Dressler, D. (1974). Transfer factor. Annals of Internal Medicine, 81 (6), 838-847.

Schumacher, H. (1974). Attempt of transfer-factor therapy of subacute sclerosing panencephalitis. Monatsschrift Kinderheilkunde, 122 (7), 429-430.

Schwarz, M. A., Gutterman, J. U., Burgess, M. A. et al. (1980). Chemoimmunotherapy of Disseminated Malignant Melanoma with OTIC-BCG, Transfer Factor + Melphalan. Cancer, 45, 2506-2515.

Sepiashvili, R. I. (2000) Immunorehabilitology turn of the century. International Journal of Immunorehabilitation, $1(2), 5-10$.

Shuyumbaeva, G. V. (2006). The effectiveness of Transfer Factor Plus with candidiasis, herpes infection. Kazakhstan. Meditsinky Astana Journal, 4, 208-209.

Side, A. G. (2013). Place of Transfer Factor in Treatment and Prevention of Infectious Diseases in Children and Adults. Moscow.

Simko, M., Mokrán V., Nyulassy, S. (1997). Immunomodulatory therapy of epilepsy with transfer factor. Bratislavske Lekarstve Listy, 98 (4), 234-237.

Spitler, L. E., Levin, A. S., Fudenberg, H. H. (1975). Transfer factor II: Results of therapy. Birth Defects Original Article Series, 11 (1), 449-456. 
Alexey Ya. Chizhov, Algimantas Kirkutis, Artūras Razbadauskas, Jurgita Andruškienė

Spitler, L. E., Levin, A. S., Stites, D. P. et al. (1972). The Wiskott-Aldrich syndrome. Results of transfer factor therapy. Journal of Clinical Investigation, 51 (12), 3216-3224.

Steele, R. W., Myers, M. G., Vincent, M. M. (1980). Transfer factor for the prevention of varicella-zoster infection in childhood leukaemia. New England Journal of Medicine, 14, 303 (7), 355-359.

Steele, R. W. (1980). Transfer factor and cellular reactivity to varicella-zoster antigen in childhood leukaemia. Cell Immunology, 15, 50 (2), 282-289.

Unicomb, L. E., Faruque, S. M., Malek, M. A. et al. (1996). Demonstration of a lack of synergistic effect of rotavirus with other diarrheal pathogens on severity of diarrhoea in children. Journal of Clinical Microbiology, 34, 1340-1342.

Viza, D., Fudenberg, H. H., Palareti, A. et al. (2013). Transfer factor: An overlooked potential for the prevention and treatment of infectious. Review article. Folia Biologica (Praha), 59, 53-67.

Vorobyov, A. A., Tel'nykh, N. V., Halturina, E. O. et al. (2004). Immunorehabilitation in infectious and inflammatory diseases using somatic Transfer Factor. Methodological letter. Moscow.

Zduńczyk, A. (1980). Transfer factor (its use in immunotherapy of neoplasms and other diseases. Wiadomosci Lekarskie, 1, 33 (11), 877-881.

IMUNOKOREKTORIAUS PERDAVIMO FAKTORIAUS TM

(TRANSFER FACTOR TM) TAIKYMO IMUNOPROFILAKTIKOS IR IMUNOREABILITACIJOS PROGRAMOSE PERSPEKTYVOS

\author{
Alexey Ya. Chizhov ${ }^{1}$, Algimantas Kirkutis ${ }^{2}$, Artūras Razbadauskas ${ }^{2}$, \\ Jurgita Andruškienè $\dot{2}^{2,3}$ \\ Maskvos Rusijos Tautu draugystès universiteto Ekologijos departamentas, \\ Moksline konsultacine JAV kompanijos „, LLife Research“ Taryba ${ }^{\text {, }}$ \\ Klaipédos universitetas ${ }^{2}$, \\ Klaipédos valstybine kolegija ${ }^{3}$
}

\title{
SANTRAUKA
}

Tyrimo pagrindimas. Žmogaus sveikatą didžiaja dalimi lemia organizmo atsparumas žalojantiems veiksniams ir imuninès sistemos funkcinè būklè. Naujos kartos imunomoduliatorių panaudojimas ligų profilaktikai yra daug žadantis.

Tikslas - remiantis moksline literatūra, nustatyti imunokorektoriaus Perdavimo faktoriaus $^{\mathrm{TM}}$ (TRANSFER FACTOR ${ }^{\mathrm{TM}}$ ) taikymo imunoprofilaktikos ir imunoreabilitacijos programose perspektyvas.

Metodai. İ sisteminę literatūros apžvalgą įtraukti 77 moksliniai straipsniai ir konferencijų medžiaga anglų kalba, publikuota nuo 1949 iki 2016 metų. Mokslinių šaltinių atrankos kriterijus - klinikinis tyrimas arba literatūros apžvalga, analizuojanti imunokorektoriaus poveikị žmogaus sveikatos būklei, esant skirtingiems sveikatos sutrikimams.

Rezultatai. Perdavimo faktoriai yra molekulès, kurios, donoro perduotos recipientui, sąveikauja su antigenine imunologine informacija ląstelès viduje. Žin- 
duolių, įskaitant žmogų, perdavimo faktoriai yra mažos molekulès nuo 3,500 iki 10,000 daltonų. Perdavimo faktoriaus poveikis ląsteliniam imunitetui, nespecifiniam imuniniam aktyvumui skiriasi nuo antikūnų funkcijų. Perdavimo faktoriai skirstomi ị tris frakcijas: induktorius, kurie skatina greitą imunini atsaką ir imuninès sistemos bendrą parengtị; supresorius, kurie reguliuoja imuninio atsako intensyvumą, apsaugodami nuo alerginių ir autoimuninių reakcijų; antigenui specifiškus perdavimo faktorius, atpažįstančius tam tikrus antigenus ir leidžiančius imuninei sistemai prisitaikyti ir greitai atpažinti daugumą bakterijų bei virusų.

Išvados. Perdavimo faktoriai neturi šalutinio poveikio ir yra itin veiksmingi gydant infekcines, parazitines, onkologines, dermatologines, venerines ir somatines ligas, tačiau yra labai rekomenduojami ir ligų profilaktikai bei senejjimo lètinimui.

Raktažodžiai: perdavimo faktorius, imunoprofilaktika, imunoreabilitacija. 